\title{
List of Maps
}

I Range of Nenets territory showing political boundaries $\quad 6$

2 Indigenous peoples of the Tiumen Oblast 7

3 The Yamal Peninsula $\quad$ I2

$4 \quad$ Princedoms in Northwestern Siberia $\quad 46$

5 Trade posts on the Yamal Peninsula, I935-1936 76

6 Areas of twentieth-century rebellions in

$\begin{array}{ll}\text { Northwestern Siberia } & 8 \mathrm{I}\end{array}$ 
